\title{
THE CONCEPT OF «GRATITUDE» AS A VERBAL AND VALUABLE DOMINANT OF MEDIATEX (on the example of Thanksgiving day)
}

\author{
Yaremenko Ludmila \\ Senior lecturer \\ ORCID ID 0000-0002-1167-8744 \\ Sumy State University \\ 2, Rymskoho-Korsakova St, Sumy, 40007, Ukraine \\ ludmila_yaremenko@ukr.net
}

The article is devoted to the study of the concept of "gratitude» relevant in modern discourse on the material of the media texts combined in the book Thanksgiving day (of the daily All-Ukrainian newspaper «Day»). An attempt is made to determine the conceptual content of the concept of "gratitude» through the verbalized means of objectifying this ethnocultural formation.

The concept of "gratitude» in the analyzed texts plays the role of the semantic dominant, viewed through the prism "Without memory there is no gratitude, and without gratitude there is no historical (institutionalized) memory" which defined their semantic structure.

An attempt was made to identify the axiological potential of "gratitude» as the dominant of a nonfiction text, where expressive expression is a means of achieving maximum impact on the reader. The leading meanings-values are gratitude-self-esteem, gratitude-happiness, universal cultural regulation.

Keywords: gratitude, concept, dominant, value appraisal, meaning, axiological potential

\section{КОНЦЕПТ «ВДЯЧНІСТЬ» ЯК ВЕРБАЛЬНА ТА ЦІННІСНО-СМИСЛОВА ДОМІНАНТА МЕДІАТЕКСТУ (на прикЛаді книги «День вдячності»)}

\section{Яременко Людмила}

Старший викладач

ORCID ID 0000-0002-1167-8744

Сумський державний університет, вул. Римського-Корсакова, 2, м. Суми, 40007, Україна ludmila_yaremenko@ukr.net

Стаття присвячена дослідженню актуального у сучасному дискурсі концепту «вдячність» на матеріалі медіатекстів, об'єднаних у книзі "День вдячності» (щуоденної Всеукрайнської газети «День»). Робиться спроба визначити понятійне наповнення концепту «вдячність» через вербалізовані засоби об'єктивації иього етнокультурного утворення.

Конщепт «вдячність» в аналізованих текстах відіграє роль смислової домінанти, щзо розглядається через призму "Без пам'яті немає вдячності, а без вдячності немає історичної (інституалізованої) пам'яті», яка й визначила його смислову структуру.

Зроблена спроба виявити аксіологічний потенціал «вдячності» як домінанти публіцистичного тексту, де експресивність вислову $\epsilon$ засобом досягнення максимального впливу на читача/ реціпієнта. Провідними смислами-цінностями $\epsilon$ вдячність -самоповага, вдячність - щастя, загальнокультурний регулятив.

Ключові слова: вдячність, концепт, домінанта, ціннісна оцінка, смисл, аксіологічний потенціал

(C) Yaremenko L., 2020 
У сучасному дискурсі активно використовується така модель репрезентації знань як «концепт» (від лат. conceptus - думка, поняття, смисл), що увійшов у науковий обіг у 90-их рр. ХХ ст. Дефініцію терміна, його сутність та природу, багатошарову структуру, закономірності функціонування у різних наукових площинах досліджували вітчизняні мовознавці: Ю. Степанов, Н. Арутюнова, Н. Рябцева, В. Карасик, Б. Борухов, Р. Розіна, О. Кубрякова, С. Нікітіна, Т. Радзієвська, А. Вежбицька, В.Телія, Н. Слухай, І. Літвінова (Дишлюк), О. Зайченко та ін. Найбільш грунтовно аналізується науковцями концепт як етнокультурне утворення або етноконцепт. «Ця модель базована на усвідомленні того значення, яке має національна культура в житті соціуму і відображає уявлення про те, що концепт як етнокультурне утворення $є$ точкою перетину світу культури й індивідуальних смислів» $[1$, с. 269].

На часі є питання співвідношення концепту зі значеннями мовного знака, можливостями моделювання концепту. Набутки в цій царині представлені зокрема в колективній монографії «Концепти і контрасти» (Одеса, 2017), окремий розділ якої присвячений мовній репрезентації концептів у різних типах дискурсу (політичному, мас-медійному, діловому тощо), контрастуванню індивідуальних концептів у складі авторської КС (картини світу) та ін. [2]. Репрезентації через текст концептуальної моделі певних світоглядних понять українців присвячений ряд дисертаційних досліджень останніх десяти років, зокрема Н. В. Вдовиченко (Одеса, 2015) [3], А. П. Болотнікова (Полтава-Запоріжжя, 2018) [4] та ін.

У сучасній лінгвістиці активно вивчаються й реконструюються різні концепти, серед яких «життя», «мрія», «рідний край», «Україна», «Київ», «сон», «любов», «кохання», а також морально-етичні - «добро», «зло», «гріх», «сором», «благодать», «спасіння», «свобода» тощо.

До морально-етичних концептів як лінгвокультурних універсалій (за $\mathrm{H}$. Вдовиченко) відноситься й концепт «вдячність». Перш ніж говорити про глибинне мовно-інформаційне наповнення концепту «вдячність», слід акцентувати увагу на трактовці Ю. Степановим поняття «концепт» - «концеепти не лише мисляться, вони переживаються...» і далі цитуємо за I Літвіновою, - це “ніби згусток культури у свідомості людини; те, у вигляді чого культура входить у ментальний світ людини. I, 3 другого боку, концепт - це те, посередництвом чого людина - пересічна, звичайна людина, не “творець культурних цінностей” - сама входить у культуру, а в деяких випадках і впливає на неї.... Вони - предмет емоцій, симпатій і антипатій, а іноді й зіткнень. Концепт - основна чарунка культури в ментальному світі людини” [5, с.6].

Концепт «вдячність», що переживається (за Ю. Степановим), на нашу думку, дотичний до змісту концепту «ввічливість», разом репрезентують один із елементів комунікативної свідомості членів української етноспільноти [4, с.37].

Мовознавець С. Богдан зазначає, що слова дяка, подяка, дякувати прийшли в українську мову з д. нім. Dank, danken через чеську, потім польську мови. У XVII ст. (Лексикон 1627p.) - ст. сл. благодареніє словами “дякованьє албо доброє подякованньє” [5, с. 283]. Російськомовне благодарить зі ст. сл. благодарити является калькой греч. eucharistein «быть благодарным», где еu - благо «хорошо», charistein от charizomai «дарить (делать) приятное», корень char- «прелесть, милость, красота» (Цыганенко Г. Этимологический словарь, 1989).

У «Словарі української мови» 1909 р. (Б. Грінченка) подана дефініція іменника «дяка» як благодарность, і друге значення - «2) Охота, желаніе. Як маш дяку, що зроб. Вх. Лем. 413». Дієслово «дякувати» - «Благодарить. Дякує красно. АД. І. 16. Дякую тобі, мати, да що ти породила, тілько не дякую, що не оженила. Чуб. Чого сидиш, Марусенько, чом не дякуєш батеньку? Мет. 225. Ой не дякуй мені, брате. К. Досв. 84. Дя́кувати Господе́ві. Благодаря Бога» [6, с. 283]. Отже, стрижневе значення - благо дарить словами, дарувати милість , красу.

Сучасний словник української мови фіксує таку дефініцію слова «вдячність» та діал. «вдяка» - «Почуття подяки, готовність віддячити за послугу, допомогу, 
зроблене добро». Семантика слова розширена: «Який виправдовує покладені на нього надії, ставлення до нього і т. ін. [7, с. 79]. У трактуванні «подяки» додається «... вияв цього почуття. // Слова, які виражають вдячність, спасибі. // Офіційна позитивна оцінка чиєї-небудь діяльності, праці і т. ін. ... на знак готовності віддячити за послугу, допомогу, зроблене добро і т. ін.» [7, с. 825]. Семантичний ряд розширюється: не тільки почуття подяки, яке позитивно сприймається спільнотою, а й готовність його виявити, - вдячність у діï.

Сучасний філософський словник відносить «вдячність» до цінностей, (підкреслюється дискусійність цього поняття у філософії ХХ ст.) стрижневим значенням поняття $\epsilon$ «...цілісна органічна реакція людини, яка стосується прийняття або неприйняття якихось явищ... $\epsilon$ явищем внутрішнього вибору людини, людської свободи. Ц. людина не обирає, а... віднаходить себе вже інтегрованою у певні цінності або самим способом життя прилученою до них...(Підкреслено Л. Яременко). Первинна цілісна реакція прийняття або неприйняття чогось постає саме ціннісною реакцією ... регулятор людської діяльності» $[8$, с.238]. Таким чином $є$ загальнокультурними регулятивами, що ведуть до соціальної згоди (порядку).

У «Сучасному словнику з етики» «вдячність»- це «ставлення людини до того, хто зробив їй послугу, благодіяння, яке виявляється в особливому почутті готовності відповісти взаємним благодіянням». Це поняття подається дуально вдячність// невдячність - « ... В. вступає в суперечність 3 іншими принципами моралі чесності, патріотизму тощо, тобто принципами вищими від принципу В. Доводиться бути “невдячним”, наприклад, до того, хто підбиває тебе на аморальні вчинки як відплату за зроблену тобі послугу». I в якості ілюстрації в словниковій статті наводяться афоризми - "Вдячність - ознака благородства душі" (Езоп); "Вдячність борг, який потрібно сплатити, але якого ніхто не має права чекати” (Ж.-Ж. Руссо); "Вдячність більшості людей - не більше як приховане очікування ще більших благодіянь” (Ф. Ларошфуко). [9, с.71-72].

На основі наведених дефініцій можна виділити основні значення слова «вдячність» (дяка) та його дериватів вдячний , дякувати, вдячно:

1) приємні, гарні (чарівні) слова;

2) почуття подяки як вияв поваги до адресата;

3) готовність (охота, желаніе) віддячити за зроблене добро (вдячність у дії);

4) офіційна позитивна оцінка чиєї-небудь діяльності, праці;

5) вдячність не лише за зроблену послугу, але й за ту, що ще буде зроблена;

6) приховане очікування на ще більш вагомі послуги, сприяння, підтримку.

Мета наукової розвідки - визначити понятійне наповнення концепту «вдячність» через вербалізовані засоби об'єктивації цього етнокультурного утворення, що так чи інакше характеризує та ідентифікує носіїв певного етносу, шляхом лінгвістичного аналізу текстів, представлених у книзі «День вдячності» [10].

Об'єкт дослідження - мова мас-медійних текстів, об'єднаних однією стратегією та тематикою (у межах завершеного інтелектуального продукту - книги).

Предмет дослідження - концепт «вдячність» як ціннісно-смислова домінанта тексту.

Матеріалом дослідження стали окремі нариси другого розділу «Дух Слово Ідея. Образ України у світовій культурі» книги «День вдячності» (2019 р.) з бібліотеки щоденної Всеукраїнської газети «День».

Наукова новизна - концепт «вдячність» у сучасній лінгвістиці ще недостатньо вивчений і реконструйований. Робиться спроба проаналізувати цей концепт як етнокультурне утворення (етноконцепт за Н. Слухай) на перетині світу культури й індивідуальних смислів у межах мас-медійного тексту.

Книга «День вдячності» - це результат кількарічного інтелектуального проекту, що реалізовувався на шпальтах цієї всеукраїнської газети. Л. Івшина, головний редактор часопису, у «Слові до читачів» зокрема відзначила: «A naм'ять $i$ вдячність дуже тісно пов'язані, вони одна без одної не існують. Без пам'яті немає вдячності, 
а без вдячності немає історичної (інституціолізованої - Л. Івшина) пам'яті. Для нас $y$ «Дні» це дуже важливо» [10, с.5]. Принагідно слід зазначити, що одним із поштовхів до проекту й цієї книги у 568 сторінок став вчинок Мері Робінсон президента Ірландії (1990-1997), яка у 150-річницю трьохлітнього голоду в країні (забрав життя півмільйона ірландців) поїхала до американського індіанського племені чокто в штаті Оклахома, щоб подякувати йому за зібрані та надіслані навесні 1847 р. 173 долари на допомогу жертвам голоду в Ірландії. «Про шляхетні вчинки також потрібно пам'ятати,» - заявила президент М. Робінсон [там само, с.12-13].

Тут лексема «вдячність» розширює свою парадигму: вдячність (подяка) не тільки як вияв поваги до адресата, а й «... більшою мірою вдячність важлива для нас, тих, хто їі висловлюе . Вдячність - це могутній вітамін росту нації» ... «вміти бути вдячним ..., щзб вийти до того стану, коли ти відчуваєщ, щзо твориш радість $i$ можеш бути щцасливим» [10, с.19].

Тільки вдячна людина по-справжньому щаслива. Тому так важливо вчитися бути вдячним, тобто привносити свої індивідуальні інтерпретації (смисли) вдячності у даний момент і ситуацію.

Слово «дякую» - це лише необхідний мінімум. Але ще більш цінною є вдячність як дія. «Вдячність є обов'язком, а сповнення обов'язку - чеснотою» (Митрополит А. Шептицький).

Тому вважаємо слушною думку I. Літвінової, що «концепт (у нашій розвідці «вдячність») посідає своє особливе місце серед явищ дійсності як активне іï перетворення» [11, с. 9]. Маємо зафіксувати нове значення домінантного слова в парадигмі: умова громадянського зростання, щзасливого життя, передумова діï, nоруху душі.

Треба також зазначити, що концепт «вдячність» як явище активного перетворення сучасного життя українців $є$ на часі, є востребуваним у площині нашої розвідки. Про що свідчить і популярно-наукова праця (жанр визначений автором) Я. РадевичаВинницького «Неукраїнці, яким вдячна Україна» (Львів, 2015), де вміщено 78 невеликих структурно уніфікованих нарисів про людей різних національностей, що словом і ділом прислужилися Україні, вбачали в ній європейськість. Науковець зазначив: «Ми не можемо вимагати від неукраїнців симпатії, емпатії чи любові до нас, але наш святий обов'язок знати і належно цінувати навіть найменші вияви об’єктивного й адекватного ставлення до нас. ... Добрі люди та їхні добрі справи і вчинки не підлягають забуттю. Це не лише гідний звичай, а й обов'язок нації, яка себе поважає»[12, с. 5-6]. Отже, є слушною думка науковців, що наголошують: «Концепт як об'ємне ментальне утворення вбирає в себе не тільки інваріант значень слова, представляє його, а й абсорбує інваріант значень словотвірного гнізда того ж семантичного поля» [13, с.48-49].

«Вдячність» як обов'язок людини/нації, яка себе поважає, як показник європейськості. В якості прикладу, есей про кримського татарина Агатангела Кримського, одного 3 найбільших сходознавців, українського вченого, поліглота, перекладача, організатора науки, чиє ім'я Генеральна Асамблея ЮНЕСКО внесла до переліку видатних діячів світу. Одним із аспектів його внеску в українську справу, крім лексикографічної діяльності високої наукової якості, $€$ вироблення правил правопису української мови 1921,1928 рр. [12, с.302-303].

Не можемо не звернути увагу на те, що матеріалом для нашого дослідження стали окремі нариси та статті, присвячені видатним персоналіям-неукраїнцям, були підготовлені спеціально для презентації на шпальтах щоденної Всеукраїнської газети «День», для широкої цільової аудиторії - різноманітної за віковим та соціальним складом, - у межах медіатексту, публіцистичного стилю літературної мови, призначеного для передачі масової інформації. Мова аналізованих публікацій відповідно «... емоційно забарвлена, піднесена мова з ознаками вольової оцінності (у цьому значенні виступає синонімом до понять «ораторський стиль», «риторичний 
стиль»), ... мовні засоби призначені для емоційного впливу на читача, слухача» $[14$, с. 501], переконати у нагальності, важливості інформації.

Отже, зміст газетних текстів є експліцитно вираженим. «Загальновідомий вислів «Кожна доба має свою мову» насамперед стосується соціальних оцінок, що наявні в мові преси» [там само, с.323]. Науковець Т. Кузнєцова наголошує: «Концепт, таким чином, у тексті відіграє роль смислової домінанти, яка організовує його смислову структуру. Орієнтація на концепт як на репрезентант смислу тексту дозволяє розглядати його (концепт) як «резервуар» сукупності смислів-цінностей, а отже, як ціннісно-смислову домінанту мас-медійного матеріалу» [15, с. 340].

Провідним стає емоційний вплив на читача 3 ознаками вольової оцінності. Не можна не погодитися 3 думкою мовознавиці Г. Сагач, яка наголошує : «Живе слово представників 3МІ має бути на рівні прекрасного, піднесеного, позитивного, а не потворного, зниженого, негативного, маніпулятивного.... Вищий моральний імператив представників 3МІ України - гідно представляти націю! - з'єднувати, а не роз’єднувати “чистим словом правди” “згорьованих серцем людей ” [16, с.8].

Ще однією прикметною особливістю аналізованих текстів-нарисів (статей) $\epsilon$ те, що вони написані різними авторами - не тільки журналістами, а й вченимиекспертами, науковими співробітниками інститутів НАН України. Але при цьому автори є однодумцями, постійними дописувачами газети, дії котрих спрямовані на пошук “артезіанських свердловин”, « ... з яких можна взяти реально чисту воду, яку не засмітили всі популістичні віяння з їхніми «як-небудь і по-простому» [10, с.19]. Отже, внутрішня форма концепту «вдячність» (за Ю. Степановим) відкривається фахівцям. Таким чином, «... автор передає власне бачення реальної дійсності, вкладає у текст власні оцінні смисли. Читач намагається їх «упіймати», ... зрозуміти авторський задум, «прочитати» його смисл». [15, с. 340]. Що забезпечує широке аксіологічне відображення дійсності як емочіогенних смислів (символів) на рівні публіцистичного або комунікативного акту(за А. Фурманом, 2001) [17, с. 28].

Високий ступінь емоційної привабливості вже закладений у заголовку публікації. Так, нарис, присвячений О. Герцену, має назву «Трибуна совісті» і перший підзаголовок «Сдність політики та моралі за Олександром Герценом» (автор I. Сюндюков - редактор відділу «Історія та «Я» часопису); і заклик-звернення на початку: "А тим часом варто тільки відмовитися від примітивно-нігілістичного підходу до спадщини класиків («ну, що мені можуть дати Драгоманов, Чаадаєв, Грінченко, Франко, Герцен... Вони усі давно померли, а ми живі!»), і з подивом виявляєш, наскільки їхні ідеї співзвучні нашим нинішнім спорам» [10, с.220]. I риторичне питання, оптимальний засіб упливу: чим близький нашому століттю Герцен-мислитель? Кілька уроків для нащадків - 1) «Ми не лікарі, ми біль», говорив Герцен-публіцист про місію найкращих представників інтелігенції; 2) рідкісна широта світогляду Герцена-філософа - «незамкнутість думок» (за висловом філософа А. Володіна): був рішучим противником шаблонних, спрощенопримітивних відповідей на найскладніші питання буття.

У тексті нарису активно реалізується основна ознака аналізованого концепту: «Концепт актуально існує в даній мовній культурі як засіб взаєморозуміння й спілкування» [18, с. 79], тобто реалізується задум інтелектуального проекту й цієї книги «День вдячності» - «... чиї життєві долі ми маємо вивчати й пам'ятати, але ияе периі кроки й потрібний напрям» [10, с.18].

Отже, Герцен-політик прозорливо, 3 позицій гуманізму й демократизму, дав відповідь на питання: революція чи реформа? Цитуємо за автором нарису: «Новий порядок, що встановлюється, має постати не тільки мечем, що рубає, а й силою охоронною. ... він не тільки повинен врятувати все, що в ньому гідне порятунку, але й залишити на свою долю все те, що не заважає, різноманітне, своєрідне» [там само, c.222].

I. Сюндюков, автор матеріалу про О. Герцена, запрошує читачів замислитися про суть дорогоцінних історичних уроків, які співзвучні з сучасними дискусіями у 
суспільстві, нагадує, зокрема, про статтю Олександра Івановича «3 приводу листа 3 Волині» (грудень 1861p.), де головна думка така: «Визнаємо ж раз і назавжди як незмінну істину, що нікого не треба ані русифікувати, ані полонізувати, що нікому не слід заважати говорити й думати, вчитися й писати, як йому заманеться... Заради чого українець... проміняє свою рідну мову... ту, яка зберігає в його піснях усю історію його, - на мову зрадницького уряду...»[10, с.225]. I в цьому напрямку шанобливе ставлення О. Герцена до Т. Шевченка - «Шевченко - істинно народний поет, до голосу якого прислухається вся Україна», не втратило своєї актуальності 3 плином часу.

Друга постать, яка викликає в українського читача завжди первинну цілісну позитивну реакцію прийняття й схвалення, - це Антон Павлович Чехов. Автор нарису «Антон Чехов: український вимір» (С. Грабовський) зробив акцент на листах письменника, пов'язаних з Україною. Ці рядки живої чеховської мови та оцінок не потребують авторських коментарів, а просто апелюють до патріотичних почуттів, нагадують про найкращі риси української ментальності, стають регулятивами поведінки, соціальної згоди (В. Петрушенко, 2018) української спільноти ХХІ ст.. «Пишу Вам из теплого и зеленого далека... . Живу я в усадьбе близ Сум на высоком берегу реки Псла ... Вокруг в белых хатах живут хохлы. Народ все сытый, веселый, разговорчивый, остроумный... Нищих нет. Пьяных я еще не видел, а матерщина слышится очень редко, да и то в форме более или менее художественной». I далі етюдно лаконічний опис української ночі - «Тихие, благоухающие от свежего сена ночи, звуки хохлацкой скрипки... - все это так же широколиственно, как хохлацкая зелень, и поместиться в коротком письме не сумеет» [10, с. 229-230].

У листах А. Чехов часто використовує лексему “хохол" (у той час не була образливою), і себе називав “хохлом”, “малоросіянином”, пізніше використовував уже іншу, модернішу формулу - «У моїх жилах тече українська кров». Наведена автором медійного тексту одна із кількох назв народу у парадигмі Чехов і Україна, по-іншому трактована у сучасному дискурсі, викликає у читачів широку палітру асоціацій, симпатій та антипатій (за Ю. Степановим), а значить свідчить про появу нових смислів, оцінок основного концепту «вдячність», як ліки проти провінційності й меншовартості (Л. Івшина «Слово до читачів», с.19)

Так, через свій коментар С. Грабовський, автор нарису, - « ... те, що Чехов міг адекватно оцінити життя «пейзан», як він в одному з листів іронічно називає селян (утім, іронія тут радше спрямована на звичну стилістику мовлення частини тодішньої освіченої верстви, ніж на самих селян), сумнівів не викликає. Хоча б тому, що він не просто був проникливим достойником російської культури українського походження, а й вільно володів українською мовою» [там само, с.231], - конструює необхідні йому смисли. А читачі, в свою чергу, сприймають їх у різних ракурсах, із різним ступенем зрозумілості [15, с.340], змушені їх інтерпретувати.

Серед аналізованих нами текстів I. Буніну, Нобелівському лауреату, присвячене есе (проф. В. Панченка) з науковими коментарями й посиланнями. Акцентуємо увагу на двох його частинах - «Відкриття України» та «Слово о полку Ігоревім», Шевченко, Дніпрові пороги ...». Широка українська читацька аудиторія теж відкрила для себе по-новому українські дороги російського письменника, який глибоко відчував чар Украӥни (Є. Маланюк). Це відчуття екзотичного, привабливого світу України почалося $з$ прочитання ним повісті М. Гоголя «Старосвітські поміщики», 3 першої юнацької подорожі Дніпром на барці «Чайка» (влітку 1890 р.).

Як і Чехов, І Бунін відкривав “новий тип людей - малоросів”, читаємо його нотатки: «Хохли мені дуже сподобалися з першого погляду. Я одразу помітив різку відмінність між мужиком-великоросом і хохлом. ... А хохли справляють приємне враження: рослі, здорові й міцні, дивляться спокійно й лагідно, одягнені в чистий, новий одяг... I далеч ця (місця за Курськом) так живописно прикрашається курганами, що синіють, і силуетами струнких тополь на хуторах» [10, с. 241-242]. 
Отже, дещо негативний оцінний смисл «хохли» (див. вище) набуває поступово позитивної оцінки.

Історичний урок I. Буніна для сучасних українців - це в першу чергу його зачарованість «Словом о полку Ігоревім». Причому цю унікальну пам'ятку російський письменник бачив у контексті української культури, історичних пісень та дум, цілеспрямовано студіював виданий у Києві в 1874 р. том «Исторические песни малорусского народа...» I «чар» (Є. Маланюк) «Слова...» змусив I. Буніна зробити зупинку в Путивлі, під час поїздки до Києва (у 1890 р.) - читаємо буніновські рядки в есе: «За Путивлем, за древнім Путивлем, де колись плакала Ярославна, плакала рановранці на «заборолі» за Ігорем, - я покинув поїзд і вирішив іти кілька днів пішки» (див. новелу «Козацьким ходом», епіграфом до якої взято рядки зі «Слова...»- «О Днепре, словутицю! - ты пробил еси каменные горы сквозе землю Половецкую!..») [10, с. 245]. Тоді ж, улітку 1890-го, письменник побував у Каневі на Тарасовій горі. 3 почуттям глибокої поваги, пієтету назвав Т. Шевченка «украшением русской литературы», «великим украинским поэтом», «украинским кобзарем».

Важливою, на нашу думку, є ремарка, що кілька разів повторюється автором за С. Маланюком, і є рефреном у тексті - роздивлявся «гоголівськими» очима, гоголівська струна у прозі (генетичний зв'язок з великим попередником) і Україна «І думав я про те, яка прекрасна ще досі ия краӥна, над якою пронеслося стільки віків кривавих війн $і$ розбрату...». Отже, «урок» І. Буніна для української спільноти вивчати, подорожувати рідною країною, відчувати, щчо твориш радість $i$ можеш бути щзасливим» (Л. Івшина).

Постать Казимира Малевича-киянина, людини-космосу, в центрі нарису «Найвідоміший у світі киянин» (автор О. Кльосова) презентує нові оцінні смисли «вдячності» до попередніх, що стають потім «явищем внутрішнього вибору людини... людської свободи» [8, с.238]. Український філософ В. Срмоленко писав: «Людська творчість ніколи не відбувається «з нічого», еx nihilo, вона завжди ліпить щось із того, що є над головою, навколо, під ногами, у легенях, перед очима". А у Малевича перед очима була саме Україна і «... традиційні примітивні зображення та візерунки на українських хатах i стали першим знайомством Малевича 3 мистецтвом...І відтоді він почав підшукувати різноманітні можливості та форми вираження свого внутрішнього «голосу», який прокинувся там, в українському селі на Харківщині» [10, с. 263]. Автор нарису наголошує, що яскрава палітра полотен митця, зокрема «Білий квадрат на білому тлі»(1918 рік) повернулася, коли відкрився київський аспект Малевича [там само, с. 265-266]; стала зрозумілою ідея другого селянського циклу (1920- початку 30-их рр.) - «Вони (селяни) не мали облич, кінцівок, були невагомі, з опущеними донизу стопами, ніби ляльки. Люди, позбавлені міцності, схожі на святих із православних ікон, до яких митець відчував особливий трепет ще 3 юності». Так художник-громадянин переживав колективізацію та Голодомор як власне горе разом зі своїм народом. Отже, «вдячність» як пам’ять , як обов'язок людини, як елемент європейськості.

Висновки. На основі здійсненого аналізу концепту «вдячність» (від лат. conceptus - думка, поняття, смисл) нами була акцентована увага на його актуальності у сучасному дискурсі. Концепт «вдячність» у сучасній лінгвістиці відноситься до морально-етичних як лінгвокультурних універсалій (за Н. Вдовиченко), що є точкою перетину світу національної культури й індивідуальних смислів.

Визначено понятійне наповнення концепту «вдячність» через вербалізовані засоби його об'єктивації. Виділяємо основні значення слова «вдячність» (варіант «дяка») та його дериватів вдячний, дякувати, вдячно: 1) приємні, гарні (чарівні) слова; 2) почуття подяки як вияв поваги до адресата; 3) готовність (охота, желаніе) віддячити за зроблене добро (вдячність у дії); 4) офіційна позитивна оцінка чиєїнебудь діяльності, праці; 5) вдячність не лише за зроблену послугу, але й за ту, що ще буде зроблена; 6) приховане очікування на ще більш вагомі послуги, сприяння, підтримку. 
Оскільки матеріалом дослідження були окремі мас-медійні тексти реалізованого у книзі «День вдячності» інтелектуального проекту щоденної Всеукраїнської газети «День», відправною точкою аналізу послужила концепція цього проекту: «А пам'ять і вдячність дуже тісно пов'язані, вони одна без одної не існують. Без пам'яті немає вдячності, а без вдячності немає історичної (інституціолізованої - Л. Івшина) пам'яті. Для нас у «Дні» це дуже важливо» $[10$, c.5]. Були взяті до уваги й стилістичні особливості мас-медійних текстів, акцентована увага на емоційно забарвленій мові викладу з ознаками вольової оцінності [14, с.501].

Концепт «вдячність» в аналізованих текстах відігравав роль смислової домінанти, яка визначала його смислову структуру. Зроблена спроба виокремити парадигму смислів-цінностей, що утворюють цю домінанту: умова громадянського i національного зростання, елемент самоповаги людини (ліки проти провінційності й меншовартості), показник європейськості, вміння бути вдячним, вдячність у дії, усвідомлення вдячності як передумови щасливого життя. Ці ціннісні реакції читачів повинні стати загальнокультурними регулятивами, що ведуть до соціальної згоди, порядку [8, с.238].

Піднята нами тема потребує подальшого опрацювання, щоб вона отримала грунтовне завершення.

\section{СПИСОК ВИКОРИСТАНИХ ДЖЕРЕЛ}

1. Юрченко О. В. Дефініція концепту в сучасних лінгвістичних дослідженнях / О. В. Юрченко. - Вісник Запорізького національного університету. Філологічні науки. - 2008. - №2. - С.268-272.

2. Концепты и контрасты : монография / Н. В. Петлюченко, С. И. Потапенко, О. А. Бабелюк, Е. Л. Стрельцов и др. ; под. ред. Н. В. Петлюченко. - Одесса : Издательский дом «Гельветика», 2017. - 632 с.

3. Вдовиченко Н. В. Вербалізація морально-етичних концептів в українській мовній картині світу. Дисертація на здобуття наук. канд. філол. наук/ Н. В. Вдовиченко. Одеса, 2015. - 212c. - [Електронний ресурс]. - Режим доступу: http://onu.edu.ua/pub/bank/userfiles/files/science/rada\%20philology/Автореферат\%20 Вдовиченко.pdf

4. Болотнікова А. П. Граматичні індикатори вираження категорії ввічливості в українській мові. Дисертація на здобуття наук. канд. філол. наук/А. П. Болотнікова. - Полтава-Запоріжжя, 2018. - 257c. - [Електронний ресурс]. http://phd.znu.edu.ua/page/dis/02_2018/Bolotnikova_dis.pdf.

5. Богдан С. К. Мовний етикет українців: традиції і сучасність/ С. К. Богдан. - К. Рідна мова, 1998. - 475с.

6. Словарь української мови: в чотирьох томах /упоряд. 3 додатком власного матеріалу Б. Грінченко. - К. : Наукова думка, 1996. - Т.1 А-Ж. - 496 с.

7. Великий тлумачний словник сучасної української мови/ Укладач і голов. ред. В. Т. Бусел. - К. ; Ірпінь : ВТФ «Перун», 2004. - 1440с.

8. Петрушенко В. Л. Філософський словник: терміни, персоналії, сентенції: навчальний посібник/ В. Л. Петрушенко. - Львів: «Магнолія 2006», 2018. - 356с.

9. Тофтул М. Г. Сучасний словник з етики : словник/ М. Г. Тофтул. - Житомир : Вид-во ЖДУ ім. І. Франка, 2014. - 416с.

10. День вдячності/ За редакцією Лариси Івшиної. - Видання перше. К. : Тов. «Українська прес-група», 2019. - 568c.

11. Літвінова I. Поняття «концепт» у сучасному мовознавстві/ I. Літвінова. [Електронний ресурс]. - Режим доступу: https://drive.google.com/file/d/1T3kb2HTWtcOu2mnVHvfg9VczNMAOEXH/view

12. Радевич-Винницький Я. Неукраїнці, яким вдячна Україна/ Ярослав РадевичВинницький. - Львів: Апріорі, 2015. - 536с. 
13. Літяга В. Поняття «концепт» у парадигмі сучасних лінгвістичних досліджень/ В. Літяга. - [Електронний ресурс]. - Режим доступу: file:///C:/Users/1/Downloads/VKNU_If_2013_1_15\%20(8).pdf

14. «Українська мова». Енциклопедія/ Редкол. : Русанівський В. М., Тараненко О.О. (співголови), М. П. Зяблюк та ін. К. : «Укр. енцикл.», 2000. - 752c.

15. Кузнєцова Т. В. Методологічні засади дослідження ціннісного потенціалу медіа тексту/ Т. В. Кузнєцова// Концепты и контрасты : монография / Н. В. Петлюченко, С. И. Потапенко, О. А. Бабелюк, Е. Л. Стрельцов и др. ; под. ред. Н. В. Петлюченко. - Одесса : Издательский дом «Гельветика», 2017. - С. 339-346.

16. Сагач Г. Доля України - у нас самих!/ Г. Сагач. - Психологія і суспільство. 2001. - №1. - C. 4-8.

17. Фурман А. Українська ментальність та ії культурно-психологічні координати/ А. Фурман. - Психологія і суспільство. - 2001. - №1. - С. 9-73.

18. Зайченко О. Поняття «концепт», його загальна характеристика/ О. Зайченко. [Електронний ресурс]. - Режим доступу: file:///C:/Users/1/Downloads/Nznuoaf_2012_24_2\%20(3).pdf

\section{REFERENCES}

1. Yurchenko O. V. Concept definition in modern linguistic research. Bulletin of Zaporizhzhya National University of Philological Sciences. 2008. № 2, pp. 268-272.

2. Concepts and contrasts: a monograph, Odessa: Publishing House "Gelvetika", 2017, $632 \mathrm{p}$.

3. Vdovichenko N. V. Verbalization of moral and ethical concepts in the Ukrainian linguistic picture of the world. Odessa.2015. 212 p.

4. BolotnIkova A. P. Grammatical indicators of politeness in the Ukrainian language, Poltava-Zaporozhye, 2018257 p.

5. Bogdan S. K. Linguistic etiquette of Ukrainians: traditions and modernity.C/ Native language, $1998.475 \mathrm{p}$.

6. Dictionary of Ukrainian language in four volumes. K.: Scientific thought, Vol.1,1996,496 p.

7. A great explanatory dictionary of modern Ukrainian language. V. T. Busel. Irpin : VTF «Perun»,2004,1440 p.

8. Petrushenko V. L. Philosophical Dictionary: terms, personalities, sentiments. Lviv: «Magnoliya 2006»,2018. 356 p.

9. Toftul M. G. Modern Dictionary of Ethics. Zhitomir : Pub: Im.. I. Franka, 2014, 416 p.

10. Thanksgiving / Edited by Larissa Ivshina. $1^{\text {st }}$ pub. «UkraYinska pres-grupa»,2019, $568 \mathrm{p}$.

11. Litvinova I. The meaning of "concept" in modern linguistics [El. adress] file:///C:/Users/1/Downloads/VKNU_If_2013_1_15\%20(8).pdf

12. Radevich-Vinnitskiy Ya. Non-Ukrainians who are grateful to Ukraine. Lviv: Apriori, $2015.536 \mathrm{p}$.

13. Lityaga V. The subject of "concept" in the paradigm of modern linguistic research/[El.adress]. file:///C:/Users/1/Downloads/VKNU_If_2013_1_15\%20(8).pdf

14. "Ukrainian language". Encyclopedia 2000. - 752 p.

15. Kuznetsova T. V. Methodological bases of research of value potential of media text. Odessa: Publishing House "Gelvetika", 2017, pp. 339-346.

16. Sagach G. The fate of Ukraine is ours! Pub: Psychology and society Vol.1 pp. 4-8.

17. Furman A. Ukrainian mentality and its cultural and psychological coordinates. Pub: Psychology and society Vol.1,2001, pp .9-73.

18. Zaichenko O. Poniattia «kontsept», yoho zahalna kharakterystyka/ O. Zaichenko. [Elektronnyi resurs]. - Rezhym dostupu: file:///C:/Users/1/Downloads/ Nznuoaf_2012 _24_2\%20(3).pdf

Надійшла до редакиії 30 квітня 2020 р. 